\title{
Correlation between chronic inflammation, immunostaining and parasite load in the genital system of female dogs naturally infected with Leishmania infantum
}

\section{Correlação entre inflamação crônica, imunomarcação e carga parasitária no sistema genital de cadelas naturalmente infectadas com Leishmania infantum}

\author{
Vinícius Vasconcelos Gomes de Oliveira ${ }^{\mathrm{I}^{*}, \text { IV }}$ Simone Regina Barros de Macedo \\ Flábio Ribeiro de Araújo ${ }^{\text {II }}$ Carlos Alberto do Nascimento Ramos ${ }^{\text {II }}$ \\ Rafael Antonio Nascimento Ramos ${ }^{\text {III }}$ Frederico Celso Lyra Maia ${ }^{\text {III }}$ \\ Leucio Câmara Alves ${ }^{\text {III }}$ Valdemiro Amaro da Silva Junior III
}

ABSTRACT

The aim of the present study was to investigate the correlations among chronic inflammatory reaction, immunostaining and parasite load in the genital system of female dogs naturally infected with Leishmania infantum. Animals $(n=10)$ used in this study were from the Department of Vector Control and Animal Surveillance of the municipality of Caruaru, state of Pernambuco, Brazil. Fragments of the vulva, vagina, cervix, uterine body, uterine horns and ovaries were submitted to histopathological analysis, immunohistochemistry (IHC) and DNA detection of amastigotes by qPCR. Correlations were found between the IHC findings and chronic inflammatory infiltrate related to $\mathbf{L}$. Infantum only in the vulva and vagina; whereas, the same inflammatory reactions without immunostaining were observed in all organs, except the ovaries. L. Infantum DNA was detected in all organs of genital system, with no difference in parasite load observed among the different organs. No correlation was reported between parasite load and inflammatory lesions in the organs evaluated, except for the uterine body, in which an inverse correlation was detected. In conclusion, the vulva and vagina were the major sites of lesions and immunostaining for $\boldsymbol{L}$. Infantum amastigotes in the genital system of female dogs. Moreover, parasite load exerted no influence on the intensity of the lesions in the organs evaluated.

Key words: canine visceral leishmaniasis, genital pathology, immunohistochemistry, qPCR.

\section{RESUMO}

Considerando a falta de estudos sobre lesões nos órgãos genitais de cadelas naturalmente infectadas por Leishmania infantum, o objetivo do presente estudo foi investigar a correlação entre reação inflamatória crônica, imunomarcação e carga parasitária, no sistema genital. Dez animais foram fornecidos pelo Departamento de Controle de Vetores e Vigilância Animal do município de Caruaru, Estado de Pernambuco, Brasil. Fragmentos de vulva, vagina, cérvix, corpo do útero, corno do útero e ovários foram avaliados por descrição histopatológica, imunohistoquímica (IHQ) e detecção de DNA de formas amastigotas por qPCR. A relação entre IHQ e infiltrado inflamatório crônico relacionado com $\mathbf{L}$. infantum foi observada apenas na vulva e vagina, enquanto as mesmas reações sem imunomarcação foram observadas em todos os órgãos, exceto nos ovários. DNA de $\boldsymbol{L}$. infantum foi detectado em todos os órgãos do sistema genital, porém, sem diferença de carga parasitária entre eles. Não houve correlação entre a carga parasitária e lesões inflamatórias nos órgãos avaliados, com exceção do corpo do útero, em que foi encontrada uma correlação inversa. Em conclusão, a vulva e a vagina foram os principais locais de lesões e imunomarcação para formas amastigotas $\mathbf{L}$. infantum no sistema genital de cadelas. A carga parasitária não influenciou a intensidade das lesões nos órgãos avaliados.

Palavras-chave: leishmaniose visceral canina, patologia genital, imunohistoquímica, $q P C R$.

\section{INTRODUCTION}

Infection by $\boldsymbol{L}$. infantum causes visceral leishmaniasis (VL), which is a chronic disease with a variety of forms and lesions due to complex hostparasite interactions and immune responses in dogs

IDepartamento de Morfologia e Fisiologia Animal, Universidade Federal Rural de Pernambuco (UFRPE), Rua Dom Manoel de Medeiros s/n, Dois Irmãos, 52171-900, Recife, PE, Brasil. E-mail: vinicius-vasconcelos@hotmail.com. *Corresponding author.

IÍ́rea de Saúde Animal, Embrapa Gado de Corte, Avenida Rádio Maia 830 - Zona Rural, Campo Grande, MS, Brasil.

III Departamento de Medicina Veterinária, Universidade Federal Rural de Pernambuco (UFRPE), Rua Dom Manoel de Medeiros s/n, Dois Irmãos, Recife, PE, Brasil.

${ }^{\text {IV }}$ Centro Acadêmico de Vitória, Universidade Federal de Pernambuco (UFPE), Rua Alto do Reservatório s/n, Bela Vista, Vitória de Santo Antão, PE, Brasil. 
(NAUCKE \& LORENTZ, 2012). Transmission occurs through the bite of sandflies infected with this protozoon (BARATA et al., 2004). However, vertical transmission (DUBEY et al., 2005; ROSYPAL et al., 2005; PANGRAZIO et al., 2009) and venereal transmission (NAUCKE \& LORENTZ, 2012) should also be considered.

Lesions related to VL have been described less frequently in the genital system of dogs in comparison to other organs (DUBEY et al., 2005; ROSYPAL et al., 2005; OLIVEIRA et al., 2012). L. infantum amastigotes have been described in the uterus (ROSYPAL et al., 2005), placenta (DUBEY et al., 2005), vulva and vaginal mucosa. The presence of the parasite in the vulva and vaginal mucosa is related to multifocal chronic inflammatory infiltrate within macrophages, lymphocytes and plasma cells (SILVA et al., 2008; OLIVEIRA et al., 2012). However, SILVA et al. (2008) detected no $L$. infantum amastigotes or lesions related to VL in the cervix, uterine body, uterine horn, uterine tubes and ovaries of naturally infected female dogs.

Various methods are currently used to diagnose infection by $\boldsymbol{L}$. infantum in dogs. Detection can be performed by parasitological (BARROUINMELO et al., 2006) and immunological tests, such as indirect immunofluorescence antibody test or enzymelinked immunosorbent assay (ELISA). However, both methods are subjected to false-negative results as well as cross-reactions with other pathogens, such as Anaplasma sp. and Ehrlichia sp. (MOREIRA et al., 2007). Immunohistochemistry (IHC) (TAFURI et al., 2004), polymerase chain reaction (PCR) and real-time PCR (qPCR) (QUEIROZ et al., 2010) are currently the most specific tests for the detection of L. infantum.

Therefore, the aim of the present study was to investigate correlations among chronic inflammatory reaction, immunostaining and parasite load in the genital system of female dogs naturally infected with Leishmania infantum.

\section{MATERIALS AND METHODS}

Animals and biological samples

All animals were provided by the Department of Vector Control and Animal Surveillance of the municipality of Caruaru, state of Pernambuco, Brazil (Latitude: $08^{\circ} 17^{\prime} 00^{\prime}$ ' S; Longitude: $35^{\circ} 58^{\prime} 34^{\prime}$ 'W). $\boldsymbol{L}$. infantum infection was confirmed using the indirect fluorescent antibody test (IFAT $\geq 40$ ), parasitological bone marrow examination, IHC and qPCR of fragments from the liver, spleen, lymph nodes and skin.
Ten stray female dogs positive for $\boldsymbol{L}$. infantum, as determined by qPCR, were submitted to euthanasia by the Department of Vector Control and Animal Surveillance following the recommendations of the Brazilian Health Ministry for the control of leishmaniasis control. After this procedure, fragments of the vulva, vagina, cervix, uterine body, uterine horns and ovaries were collected. All specimens were submitted to histopathological analysis, immunohistochemistry and qPCR.

\section{Histopathological analysis}

Samples were fixed with $10 \%$ neutral buffered formalin for 48 hours and routinely processed for embedding in paraffin. Sections $(5 \mu \mathrm{m})$ were mounted on slides and stained with hematoxylin and eosin (HE) (TOLOSA et al., 2003). All tissues were evaluated according to the type of inflammatory infiltrate, intensity of the inflammatory reactions (absent $=0$; mild $=1$; moderate $=2$; and intense $=3$ ) as well as structural damage.

Immunohistochemistry

Detection of amastigote forms of $\boldsymbol{L}$. infantum was performed following the method described by TAFURI et al. (2004). Heterologous hyperimmune serum from a dog naturally infected with $\boldsymbol{L}$. infantum (positive results of parasitological examination of bone marrow and immunofluorescence antibody test (IFAT) - title $\geq 1: 40$ ), diluted at 1:100 (0.01M PBS) was used as primary antibody. A commercially available streptavidin-peroxidase complex (LSAB+ kit, Dako USA) was employed as the detection system. Reactions were revealed by diaminobenzidine (DAB) and the slides were counter-stained with hematoxylin. IHC was scored based on the number of amastigotes observed in a high magnification microscopic field $(0=$ no amastigotes; 1 = one to three amastigotes; $2=$ four to ten amastigotes; $3=>$ ten amastigotes).

\section{Molecular diagnosis}

Genomic DNA from all samples collected as well as from an in vitro culture of $\boldsymbol{L}$. infantum was extracted using the DNeasy Blood \& Tissue Kit (Qiagen ${ }^{\circledR}$ Hilden-Germany) following the manufacturer's instructions.

The qPCR reaction for the detection of $\boldsymbol{L}$. infantum DNA was performed using primers Leish-1 [5'-AACTTTTCTGGTCCTCCGGGTAG-3'] andLeish-2 [5'-ACCCCCAGTTTCCCGCC-3'] and the TaqMan MGB-probe [FAM-5'-AAAAATGGGTGCAGAAAT-3' non-fluorescent quencher-MGB], as described by Francino 
et al. (2006). qPCR was performed in a CFX96 ${ }^{\mathrm{TM}}$ RealTime System (Bio-Rad Laboratories, Inc., Hercules CA, USA). Reaction mixture $(12.5 \mu \mathrm{L})$ contained $6.25 \mu \mathrm{L}$ of Taqman ${ }^{\circledR}$ Universal PCR Master Mix, each primer at a concentration of $900 \mathrm{nM}$, the probe at a concentration of $200 \mathrm{nM}$ and $1 \mu \mathrm{L}$ of template DNA. The run consisted of a hot start at $95^{\circ} \mathrm{C}$ for 3 minutes and 42 cycles of denaturation $\left(95^{\circ} \mathrm{C}\right.$ for 10 seconds) and annealing-extension $\left(60^{\circ} \mathrm{C}\right.$ for 30 seconds). All assays were performed in duplicate, with a negative control (DNA of a dog from a non-endemic area) and a positive control (DNA from an in vitro culture of $\boldsymbol{L}$. infantum) included in each run.

Parasite load was determined using the absolute quantification method. A standard curve was constructed with DNA extracted from serial dilutions of $\boldsymbol{L}$. infantum cultures containing approximately $5.6 \times 10^{6}$ parasites $\mathrm{mL}^{-1}$. Considering an extraction efficiency of $100 \%$, five points were used to construct the curve $(0.1,1,10$, 1000 and 1,000,000 parasites $\mathrm{mL}^{-1}$ of culture). As DNA extraction was performed using $300 \mu \mathrm{L}$ of $\boldsymbol{L}$. infantum culture, the final product of the extractions was diluted in a final volume of $100 \mu \mathrm{L}$ and $1 \mu \mathrm{L}$ of DNA was used per reaction. Points cited above correspond to $0.0003,0.003,0.03,3$ and 3000 parasites, respectively. Therefore, based on the same principle and considering that DNA extraction was performed using $25 \mathrm{mg}$ of each tissue sample, results were expressed as the number of parasites $/ 250 \mu \mathrm{g}$ of tissue.

Statistical analyses

The parasite load determined by qPCR, the number of amastigotes detected by IHC and the inflammatory score after HE staining were compared using the Kruskal-Wallis test. Spearman's test was used to determine correlations among these values. Fisher's exact test was used for comparisons of the diagnostic techniques. All analyses were performed using the $\mathrm{R}$ software version 2.15.2 (R CORE TEAM, 2012). To test the correlation values, qPCR data (parasites $250 \mu \mathrm{g}^{-1}$ of tissue) were transformed into scores according to the following criteria: $0=0 ; 0.001$ to $0.01=1 ;>0.01$ to $0.1=2 ;>0.1$ to $1=3 ;>1$ to $2=4$; $>2$ to $5=5 ;>5$ to $6=6 ;>6$ to $7=7 ; \ldots ;>100=100$.

\section{RESULTS}

No macroscopic lesions were reported on the genital organs of the dogs examined. Regarding the histopathological findings, the female genital organs exhibited histio-plasmo-lymphocytic inflammatory lesions ranging from mild to severe (Figures 1A-1D; Table 1). During immunohistochemistry, L. infantum amastigotes were detected in $50 \%(5 / 10)$ of the vulva samples (Figure 1E) and 20\% (2/10) of the vaginal samples (Figure 1F) (Table 1). No amastigote forms were reported in the cervix, uterine body, uterine horn or ovaries.

The qPCR results revealed that $\boldsymbol{L}$. infantum DNA was detected in $90 \%(9 / 10)$ of animals in at least one of the samples tested. Parasite load was low in $60 \%$ of animals (Table 2). The uterine horn and vulva exhibited $60 \%$ positivity (6/10) and the vagina exhibited $70 \%$ positivity (7/10). Cervix, uterus and ovaries exhibited $80 \%$ positivity for DNA from $L$. infantum amastigotes (8/10) (Table 1).

A statistically significant difference (Kruskal-Wallis test) was reported in the comparison of the number of parasites detected by IHC $(P=0.0019)$ and the chronic inflammatory reaction score $(P=0.0060)$ were compared. However, no differences among the organs were reported regarding parasite load determined by qPCR $(P=0.9387)$. The vulva had the highest scores using the IHC method in comparison to the other genital organs. The histopathological analysis of the ovaries and cervix revealed the lowest scores for chronic inflammatory infiltrate; whereas, the highest scores were reported in the vulva, vagina and uterine horn (Table 1).

Spearman's test demonstrated a significant negative correlation between the qPCR score and degree of inflammation in the uterine body $(P=0.001)$. However, no correlations were reported for other organs (vulva: $P=0.134$; vagina: $P=0.752$; cervix: $P=0.617$; uterine horn: $P=0.305$; ovary: $P$ not possible to determined due to a column with all values equal to 0$)$. Fisher's exact test $(P<0.001)$ revealed that qPCR $(0.28)$ was more efficient than IHC (0.90) for detection of tissue infected by amastigote forms of $L$. infantum.

\section{DISCUSSION}

L. infantum amastigotes have wide distribution in the tissues of dogs (TAFURI et al., 2004). In male dogs, several studies have demonstrated the tropism of $\boldsymbol{L}$. infantum in genital organs (DINIZ et al., 2005). However, few studies previous studies have demonstrated $\boldsymbol{L}$. infantum tropism in female genital organs of the correlation between parasite load and the onset of lesions in these organs (DUBEY et al., 2005; ROSYPAL et al., 2005; SILVA et al., 2008).

The structural changes in the vulva and vagina observed in the present investigation 


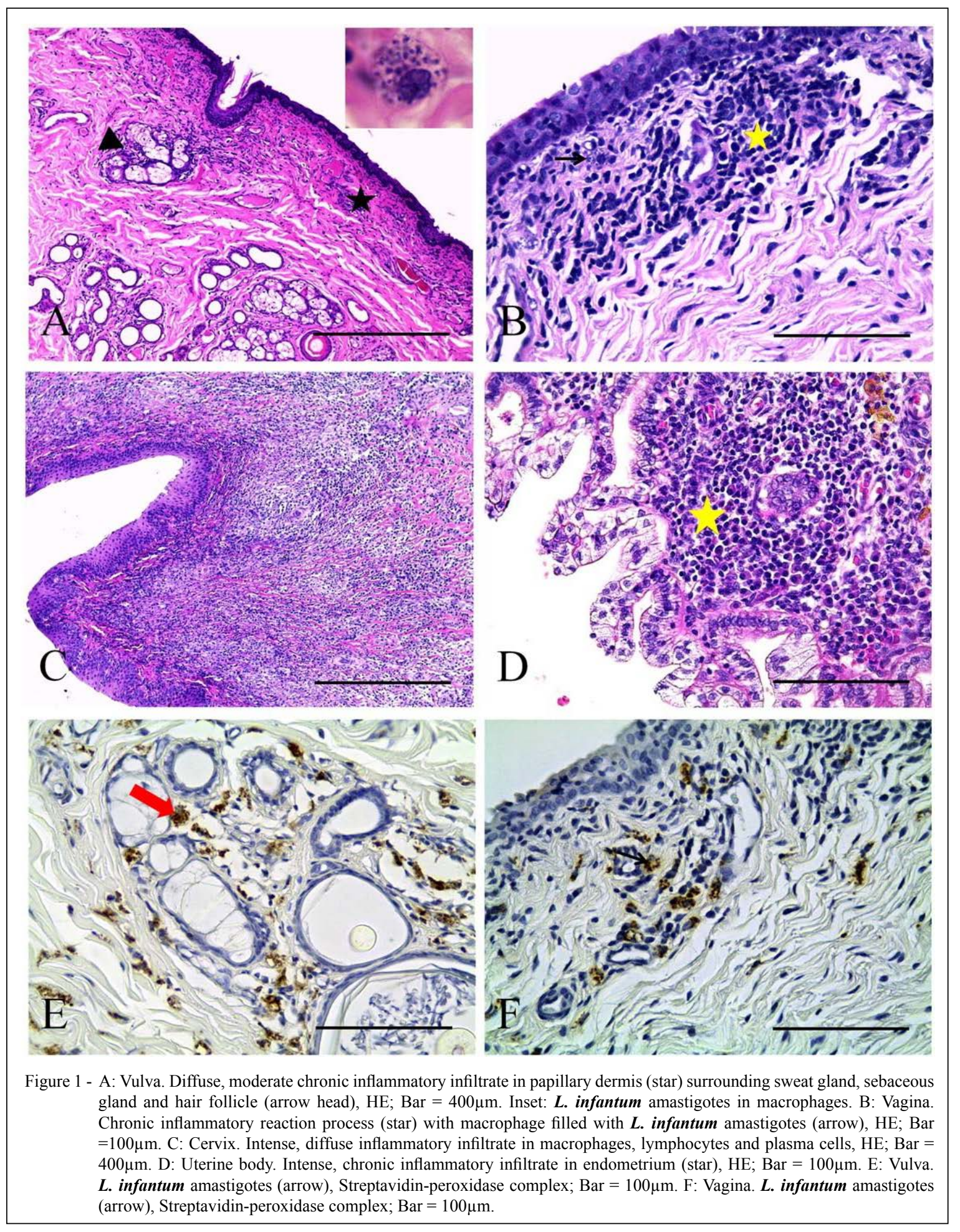

resemble change reported in previous studies (SILVA et al., 2008), in which chronic inflammatory infiltrate has been considered the only lesion detected in these organs. Lesions were frequently reported next to hair follicles, sebaceous glands and sweat glands. In the present study, besides of these lesions, chronic inflammatory infiltrate was not restricted to the external genitalia and was also reported in the cervix and uterine tissue of the animals analyzed. 
Table 1 - Absolute and relative values of histopathological lesions (HE), IHC for amastigotes, qPCR positivity and comparisons between mean ranks for each organ evaluated in the genital system of female dogs naturally infected with $\boldsymbol{L}$. infantum .

\begin{tabular}{|c|c|c|c|c|c|}
\hline \multirow{2}{*}{$\operatorname{Organ}(n=12)$} & & -----HE- & & \multirow{2}{*}{$\mathrm{IHC}$} & \multirow{2}{*}{ qPCR } \\
\hline & Mild & Moderate & Severe & & \\
\hline Cervix & $2(16.6 \%)$ & 0 & $2(16.6 \%)$ & 0 & $8(61.5 \%)$ \\
\hline Uterine horn & $1(8.3 \%)$ & $4(33.3 \%)$ & $1(8.3 \%)$ & 0 & $6(50.0 \%)$ \\
\hline Uterine body & 0 & $1(8.3 \%)$ & $3(25.0 \%)$ & 0 & $8(61.5 \%)$ \\
\hline Ovary & 0 & 0 & 0 & 0 & $8(61.5 \%)$ \\
\hline Vagina & $1(8.3 \%)$ & $5(41.6 \%)$ & $1(8.3 \%)$ & $2(16.6 \%)$ & $7(58.3 \%)$ \\
\hline \multirow[t]{4}{*}{ Vulva } & 0 & $9(75.0 \%)$ & $1(8.3 \%)$ & $5(41.6 \%)$ & $6(50.0 \%)$ \\
\hline & & qPCR & IHC & \multicolumn{2}{|c|}{ HE } \\
\hline & Cervix & $35.20^{\mathrm{a}}$ & $33.00^{\mathrm{b}}$ & \multicolumn{2}{|c|}{$32.66^{b c}$} \\
\hline & Uterine horn & $26.80^{\mathrm{a}}$ & $33.00^{\mathrm{b}}$ & \multicolumn{2}{|c|}{$38.16^{\mathrm{ab}}$} \\
\hline \multirow{4}{*}{ Organs } & Uterine body & $30.90^{\mathrm{a}}$ & $33.00^{\mathrm{b}}$ & \multicolumn{2}{|c|}{$35.70^{b}$} \\
\hline & Ovary & $30.40^{\mathrm{a}}$ & $33.00^{b}$ & \multicolumn{2}{|c|}{$21.00^{\mathrm{c}}$} \\
\hline & Vagina & $30.50^{\mathrm{a}}$ & $39.25^{b}$ & \multicolumn{2}{|c|}{$41.00^{\mathrm{ab}}$} \\
\hline & Vulva & $29.20^{\mathrm{a}}$ & $47.75^{\mathrm{a}}$ & \multicolumn{2}{|c|}{$50.45^{\mathrm{a}}$} \\
\hline
\end{tabular}

Means followed by same letter in column do not differ significantly $(\mathrm{P}>0.05)$.

Immunostaining detection for $\boldsymbol{L}$. infantum amastigotes in the vulva and vagina is in agreement with data described by SILVA et al. (2008), as these were the only organs to have amastigote forms of $\boldsymbol{L}$. infantum in macrophages. According to the authors cited, previous injuries can attract parasitized macrophages to connective tissue of the vulva and vagina. In the present investigation; however, no macroscopic lesions were reported in the female genital tract. Therefore, the macrophages normally reported in the connective tissue of the vulva and vaginal mucosa made these areas a site of parasitism for $\boldsymbol{L}$. infantum amastigotes (WATTS et al., 1998). In this context, it was not possible to establish a relationship, at least in the present study, between macrophages infected with $\boldsymbol{L}$. infantum amastigotes and pre-existing injuries.

No amastigotes were reported in the cervix, uterine body, uterine horn or ovaries. Indeed, few authors have described $L$. infantum in these organs. Conversely, L. infantum amastigotes have been frequently reported in the uterus (ROSYPAL et al., 2005) and placenta (DUBEY et al., 2005). Although previous studies have detected the presence of amastigote forms of $\boldsymbol{L}$. infantum in the uterus and placenta, these findings may be underestimated.

In the present study, the detection of $\boldsymbol{L}$. infantum DNA in all organs of the female genital system was not significantly associated with chronic inflammatory infiltrate in these tissues. In male dogs,

Table 2 - Parasite load of each biological sample from female dogs naturally infected by $\boldsymbol{L}$. Infantum.

\begin{tabular}{|c|c|c|c|c|c|c|}
\hline Animal & Cervix & Uterine horn & Uterine body & Ovary & Vagina & Vulva \\
\hline A1 & 8.56 & 6.43 & 1.455 & 0.57 & 28.991 & 0.003 \\
\hline A2 & 533.232 & 259.503 & $1,615.506$ & 519.225 & 34.254 & $84,702.805$ \\
\hline A3 & 0.322 & 0 & 0.062 & 0.163 & 0 & 0 \\
\hline A4 & 0 & 0 & 0.013 & 0 & 0 & 0.204 \\
\hline A5 & 0.72 & 3.625 & 0.503 & 0.466 & 0.049 & 0.744 \\
\hline A6 & 543.452 & 0 & 0.383 & 8.022 & $1,345.295$ & $26,447.793$ \\
\hline A7 & $1,274.93$ & 290.803 & $3,801.012$ & 116.321 & 575.396 & 0 \\
\hline A8 & 0 & 0 & 0 & 0 & 0 & 0 \\
\hline A9 & 0.178 & 0.041 & 0 & 0.092 & 0.144 & 0 \\
\hline A10 & 667.393 & 72.015 & 36.335 & 57.047 & 115.126 & $272,211.562$ \\
\hline
\end{tabular}

Results expressed as number of parasite $/ 250 \mu \mathrm{g}$ of tissue.

Ciência Rural, v.11, nov, 2016. 
L. infantum DNA has been detected in all genital organs. However, no correlation between parasite load and inflammatory lesions has been observed in these organs. Indeed, testicles have been reported to exhibit the highest parasite load as well as the lowest number of inflammatory lesions (OLIVEIRA et al., 2016).

There have been no previous data on the parasite load in the genital organs and the grade of chronic inflammatory reaction in female dogs naturally infected with $\boldsymbol{L}$. infantum. In the present study, an inverse correlation was only reported in the uterine body. According to TORRES et al. (2013), the parasite load does not influence the characteristic of renal inflammatory lesions in infected dogs. In the present study, the $\boldsymbol{L}$. infantum parasite load did not influence the intensity of chronic inflammatory lesions in the genital organs of naturally infected female dogs, except the uterine body, as described above. These findings indicated that factors other than $\boldsymbol{L}$. infantum amastigotes could be responsible for the evolution of the inflammatory reaction and lesion intensity (TORRES et al., 2013).

\section{CONCLUSION}

Leishmania infantum has tropism for organs of the reproductive system of female dogs, with the vulva and vagina the major sites of chronic inflammatory lesions and immunostaining for amastigotes. $\boldsymbol{L}$. infantum DNA and chronic inflammatory lesions were reported in all organs, except the ovaries. However, parasite load did not influence the intensity of the lesions reported in these organs.

\section{ACKNOWLEDGMENTS}

The authors thank the staff of the Department of Vector Control and Animal Surveillance of the municipality of Caruaru, particularly the veterinarian Cláudia Agra.

\section{BIOETHICS AND BIOSSECURITY COMMITTEE APPROVAL}

The present study was approved by the Ethics Committee for Animal Experimentation of the Universidade Federal Rural de Pernambuco (UFRPE) (protocol ECAE: 23082.015186/2012).

\section{REFERENCES}

BARATA, R.A. et al. Phlebotomine sandflies in Porteirinha, an area of American visceral leishmaniasis transmission in the state of Minas Gerais, Brazil. Memórias do Instituto Oswaldo Cruz, v.99, n.5, p.481-487, 2004. Available from: <http://www.scielo.br/ scielo.php?pid=s0074-02762004000500004\&script $=$ sci_arttext $>$. Accessed: Jul. 13, 2016. doi: 10.1590/S0074-02762004000500004.
BARROUIN-MELO, S.M. et al. Can spleen aspirations be safely used for the parasitological diagnosis of canine visceral leishmaniasis? A study on asymptomatic and polysymptomatic animals. Veterinary Journal, v.171, p.331-339, 2006. Available from: <http://www.repositorio.ufba.br:8080/ri/bitstream/ri/5262/1/ S1090023304002412-main.pdf $>$. Accessed: Jul. 13, 2016. doi: 10.1016/j.tvj1.2004.11.010.

DINIZ, S.A. et al. Genital lesions associated with visceral leishmaniasis and shedding of Leishmania sp. in the semen of naturally infected dogs. Veterinary Pathology, v.42, n.5, p.650-658, 2005. Available from: <http://vet.sagepub.com/ content/42/5/650.full.pdf $>$. Accessed: Jul. 13, 2016. doi: 10.1354/ vp.42-5-650.

DUBEY, J.P. et al. Placentitis associated with leishmaniasis in a dog. Journal of the American Veterinary Medical Association, v.227, p.1266-1269, 2005. Available from: <http://www. researchgate.net/publication/7502033_Placentitis_associated with leishmaniasis in a dog>. Accessed: Jul. 13, 2016. doi: $10.2 \overline{4} 60 /$ javma. $2005.2 \overline{2} 7.1266$

FRANCINO, O. et al. Advantages of real-time PCR assay for diagnosis and monitoring of canine leishmaniosis. Veterinary Parasitology, v.137, p.214-221, 2006. Available from: <http:// www.ncbi.nlm.nih.gov/pubmed/16473467>. Accessed: Jul. 13, 2016. doi: 10.1016/j.vetpar.2006.01.011.

MOREIRA, M.A. et al. Comparison of parasitological, immunological and molecular methods for the diagnosis of Leishmaniasis in dogs with different clinical signs. Veterinary Parasitology, v.145, p.245-252, 2007. Available from: <http:// www.ncbi.nlm.nih.gov/pubmed/17257764>. Accessed: Jul. 13, 2016. doi: 10.1016/j.vetpar.2006.12.012.

NAUCKE, T.J.; LORENTZ, S. First report of venereal and vertical transmission of canine leishmaniosis from naturally infected dogs in Germany. Parasites \& Vectors, v.5, p.67, 2012. Available from: $<$ http://www.parasitesandvectors.com/content/5/1/67>. Accessed: Jul. 13, 2016. doi: 10.1186/1756-3305-5-67.

OLIVEIRA, V.V.G. et al. Histopathological evaluation and parasite quantification (qPCR) in the male dog's genital system after natural infection with Leishmania infantum. Ciência Rural, v.46, n.4, p.641-647, 2016. Available from: <http://www.scielo.br/pdf/cr/v46n4/16784596-cr-46-04-00641.pdf $>$. Accessed: Jul. 13, 2016. doi: $10.1590 / 0103-8478 \mathrm{cr} 20150850$.

OLIVEIRA, V.V.G. et al. Genital pathologies associated with canine visceral leishmaniasis. Ciencia Rural, v.42, p.1614-1620, 2012. Available from: <http://www.scielo.br/scielo.php?script=sci artt ext\&pid=S0103-84782012000900016>. Accessed: Jul. 13, 2016. doi: $10.1590 / \mathrm{S} 0103-84782012000900016$.

PANGRAZIO, K.K. et al. Tissue distribution of Leishmania chagasi and lesions in transplacentally infected fetuses from symptomatic and asymptomatic naturally infected bitches. Veterinary Parasitology, v.165, p.327-331, 2009. Available from: $<$ http://www.ncbi.nlm.nih.gov/pubmed/19647368> . Accessed: Jul. 13, 2016. doi: 10.1016/j.vetpar.2009.07.013.

R CORE TEAM. R: a language and environment for statistical computing. Vienna: R Foundation for Statistical Computing. 2012. Available from: <http://www.R-project.org/>. Accessed: Nov. 22, 2012. 
ROSYPAL, A.C. et al. Transplacental transmission of a North American isolate of Leishmania infantum in a experimentally infected beagle. Journal of Parasitolology, v.91, p.970-972, 2005. Available from: <http://www.journalofparasitology.org/doi/ abs/10.1645/GE-483R.1?journalCode=para $>$. Accessed: Jul. 13, 2016. doi: 10.1645/GE-483R.1.

SILVA, F.L. et al. Genital lesions and distribution of amastigotes in bitches naturally infected with Leishmania chagasi. Veterinary Parasitology, v.151, n.1, p.86-90, 2008. Available from: <http://journals.ohiolink. edu/ejc/article.cgi issn $=03044017 \&$ issue $=\mathrm{v} 151$ i0001\&article $=86$ gladoabniwlc\&search_term $=\% 28$ refkey $\% 3 \mathrm{D} \% 28 \mathrm{Silva} \% 232008 \% 23 \overline{8}$ 6\%23*\%29volkey\%3D\%2803044017\%23151\%2386\%231\%29\%29 >. Accessed: Jul. 13, 2016. doi: 10.1016/j.vetpar.2007.09.032.

TAFURI, W.L. et al. An alternative immunohistochemical method for detecting Leishmania amastigotes in paraffin-embedded canine tissues. Journal of Immunological Methods, v.292, n.1-2, p.17-23, 2004. Available from: <http://www.ncbi.nlm.nih.gov/pubmed/15350508>. Accessed: Jul. 13, 2016. doi: 10.1016/j.jim.2004.05.009.
TOLOSA, E.M.C. et al. Manual de técnicas histológicas normal e patológica. São Paulo: Manole, 2003. 331p.

TORRES, M.M. et al. Renal parasite load association with laboratory findings in dogs with visceral Leishmaniasis. Ciencia Rural, v.43, p.894-896, 2013. Available from: <http://www.scielo.br/pdf/cr/ v43n5/a12213cr2012-0194.pdf>. Accessed: Jul. 13, 2016.

QUEIROZ, M.G.P. et al. Diagnóstico da leishmaniose visceral canina pelas técnicas de imunohistoquímica e PCR em tecidos cutâneos em associação com a RIFI e ELISA-teste. Revista Brasileira de Parasitologia Veterinária, v.19, p.34-40, 2010. Available from: $<$ http://scielo.iec.pa.gov.br/pdf/rpas/v3n2/v3n2a07.pdf $>$. Accessed: Jul. 13, 2016. doi: 10.5123/S2176-62232012000200007.

WATTS, J.R. et al. Endometrial cytology of the normal bitch throughout the reproductive cycle. Journal of Small Animal Practice, v.39, p.2-9, 1998. Available from: <http://www.ncbi.nlm. nih.gov/pubmed/9494927>. Accessed: Jul. 13, 2016. doi: 10.1111/ j.1748-5827.1998.tb03661.x.

Ciência Rural, v.11, nov, 2016. 